\title{
NEUROMARKETING IN THE CONTEXT OF SUSTAINABLE DEVELOPMENT PHILOSOPHY
}

\author{
Olena Martyniuk' ${ }^{\text {, Tetiana Poplavska² }}$
}

\begin{abstract}
This document aims to conduct a literature review in order to identify evolution and research trends in the area of neuromarketing end marketing ethics. The fact of deep systemic crisis of the modern civilization has been discussed by politicians, scientists and philosophers for at least last fifty years. Since then, more than forty of them have been published, that was base for the scientific thought development towards the formation of the concept of sustainable development of mankind. Self-healing changes are extremely slow, despite the enormous efforts of scientists, politicians and public figures. This is partly caused by the fact that in modern politics and economics the neuroscience achievements are used widely but these achievements are applied for narrowly selfish purposes that contradict the main goals and objectives of the concept of sustainable development. Therefore, it is relevant to turn to the analysis of a relatively new direction in modern economic science - neuromarketing, which is gaining the more influence in the society and is actively developing in use. As the world history experience shows, the most important prerequisite for the new civilization formation is a radical transformation of the spiritual (value-semantic) sphere of life. In turn, such transformation is unthinkable without the philosophical project of reconstruction and neoholism, the fundamental value of which is the eidos of harmony, can become such a project. In the modern world dominates the ideology of consumption, the products of which are the presence of fashion, wastefulness, profit orientation in decision making, etc. Consumption is the act of receiving goods or services. Overconsumption (or irrational consumption) that dominates in the world and is imposed by the entire marketing system is the phenomenon of receiving goods and services more than need - to a greater extent than a person needs. This is a dead end, because of which the entire system is going through a deep crisis. Some scientists believe that the way out of the crisis is possible through the interaction of science and economics, or rather neurosciences and economics, which leads to overconsumption of goods and services, which means the growth of incomes of large and medium-sized capital. Others see the way out in the new thinking development, a new philosophical paradigm, which must be introduced into the mass consciousness by means of education, thereby raising the level of consciousness and expanding the potential of a person. The most famous firms that have used neuromarketing techniques to achieve their goals are Coca-Cola, General Motors, Google Mars, Nestle and many other corporations. It is important to mention that the neuromarketing cost is increasing every year, for example, in 2015 the United States spent $\$ 25$ billion on neuromarketing research. At the present stage, there are three main research methods in neuromarketing: electrical activity of the brain (EEG), oculography (eye movement, eye tracking) and analysis of facial expressions and non-verbal gestures. For example, in the evaluation process of the TV commercials effectiveness, specialists monitor the eyes and determine the speed of pupil movement. Analyzing the above, it can be argued that neuromarketing in the modern world is one of the leading and promising technologies for the society influencing. It is possible that its potential has not yet been fully formed and studied, but these studies are the highly paid item of expenditure in the large corporations.
\end{abstract}

Key words: sustainable development, marketing ethics, neoholism, neuromarketing, neuroeconomics.

JEL Classification: M31, 010, P40

\footnotetext{
Corresponding author:

${ }^{1}$ International Humanitarian University, Ukraine.

E-mail: emartynuk2017@gmail.com

ORCID: http://orcid.org/0000-0002-0377-7881

${ }^{2}$ South Ukrainian National Pedagogical University named after K.D. Ushynsky, Ukraine.

E-mail: sofistriya@gmail.com

ORCID: https//orcid.org/0000-0003-2492-8068
}

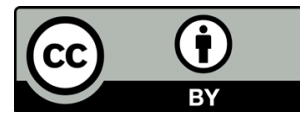

This is an Open Access article, distributed under the terms of the Creative Commons Attribution CC BY 4.0 


\section{Introducation}

The fact of deep systemic crisis of the modern civilization has been discussed by politicians, scientists and philosophers for at least last fifty years. The first attempt of scientific understanding of global problems and predictions of possible ways of human development in the context of an exacerbation of the global crisis has been made by Members of the Club of Rome in 1968. Since then, more than forty of them have been published, that was base for the scientific thought development towards the formation of the concept of sustainable development of mankind (Ursul, 2005; Nemtsev, 2015).

The main idea of this concept is that mankind needs to come to a system in which "satisfaction of the present generation needs is realized without prejudice to the ability of future generations to meet their own needs" (Lopatnikov's Dictionary), i.e., the nature possibilities are preserved to support the mankind development in the long term, considering the various spheres of national and global security.

However, as experience shows, the world continues to move along the path of unsustainable development, the number of global problems and manifestations of their negative consequences is only increasing, that makes an appeal to this matter relevant and timely.

Self-healing changes are extremely slow, despite the enormous efforts of scientists, politicians and public figures. This is partly caused by the fact that in modern politics and economics the neuroscience achievements are used widely but these achievements are applied for narrowly selfish purposes that contradict the main goals and objectives of the concept of sustainable development. Therefore, it is relevant to turn to the analysis of a relatively new direction in modern economic science - neuromarketing, which is gaining the more influence in the society and is actively developing in use.

The purpose of this paper is a critical analysis and coherent synthesis of the foundations of the neuromarketing formation and development trends as the promising direction of influence on the modern communication and business environment.

\section{Methodology of research}

\subsection{Ethical intentions of marketing technology}

Scientists believe that the neuromarketing concept was developed by psychologists of Harvard University in the 1990s. However, the founders of this direction are traditionally considered the CEO of Re tail branding AG Arndt Tryndl and the director of the store branding Re tail branding Bart Oeyman (Murphy, Illes, Reiner, 2008).

A general neuromarketing method was developed in the late 1990s by Harvard professor Jerry Zultman, who immediately patented it under the name ZMET
(Zaltman Metaphor Elicitation Method). The essence of ZMET is to recognize the person's subconscious with the help of sets of specially selected pictures that cause a positive emotional response and activate hidden images-metaphors that stimulate purchase. Based on the identified images, graphic collages are constructed, which are used as the basis for commercials. After that the data is interpreted through conversations with psychologist or by analyzing images of the brain.

Marketing technology ZMET has gained popularity quickly among hundreds of large customer firms, among which are Coca-Cola, Pepsi, Nestle, General Motors, Procter \& Gamble, and others (more than two hundred large companies).

According to F. Kotler, today neuromarketing has developed to the full-fledged marketing direction (Knutson, Rick, Wimmer, Prelec, Loewenstein, 2007; Bird, 2006).

The neuromarketing technology is based on the model according to which the bulk (more than 90\%) of a person's mental activity, including emotions, occurs in the subconscious area, that is below the levels of controlled awareness (Bird, 2006).

Even though neurobiological research in the field of human decision-making has been carried out for a long time, neuro scanning technology was first used exclusively for marketing purposes by the already mentioned Professor Zaltman in the late 1990s. The term "neuromarketing" was proposed by Professor Smids in 2002, and the first international conference entirely devoted to neuromarketing research was held only in 2004 in the United States. It can be noted that neuromarketing is a very young discipline, the prerequisites for the formation of which go into the field of neurobiology and medical research, which appeared long before the concept of neuromarketing formation (Lim, 2018).

The neuromarketing concept assumes that that a person perceives environmental irritants (for example, product presentation), first, at the level of neurophysiological signals. They are translated by the senses through biophysical and biochemical processes into the language of emotions even at the subconscious level, the limbic system - the deep subcortex of the brain, which determines the type of the emotional system. Today the conceptual neuromarketing platform is based on the works of Jerry Zultman, Arndt Trindl, Bart Oyeman, Martin Lindstrom, David Lewis, Roger Dooley and others.

In the scientific community there is an information about the direct use of magnetic resonance imaging equipment in the neuromarketing research. An American scientific and commercial project called the Brighthouse Institute for the Thought Sciences became a pioneer in this field at the turn of 2002 and 2003. The new MRI-based neuromarketing technique 
developed by the mentioned Institute is like ZMET and it also uses specially selected images. The only difference is that the reaction of the surveyed clients to the presented images is established not by the psychologist's conversation, but by the direct scanning and analysis of the brain regions activated in this case.

However, during the studying of the positive and negative reactions of the brain to certain images, neuromarketologists are not interested in the conscious reaction of a person. The reason is the stated goal of the study - to establish how effective advertising is in subconsciously stimulating the purchase of a particular product or in developing brand loyalty (Lindstrom, 2012).

Thus, marketers in their arsenal have the latest equipment that helps them to study our memory, to predict the memorability of key messages using EEG and questionnaires; our attention, using eyetracking technology to decipher priority attention to understand what arouses our interest; our emotions using EEG to analyze engagement and motivation; cognitive interest to determine the degree of information complexity to understand and determine the relevance degree of any message, and finally, our motivations underlying our desires!

Moreover, scientists are interested why we make mistakes, why we take risks, love, laugh, etc. Neuroeconomics uses a technique called transcranial magnetic stimulation (TMS) (Plassmann, O'Doherty, JShiv, Rangel, 2008). Scientists use electromagnetic coils that create a strong magnetic field that can be directed accurately to the specific brain area and, for example, temporarily suppress a few millimeters of the frontal cortex and observe what happens. Professor, Head of the Department of Psychology, Leading Researcher at the Center of Neuroeconomics and Cognitive Research of National Research University "Higher School of Economics" Vasily Klyucharev states in his interview: "The neuroeconomic experiments of our colleagues in Zurich have shown that in this way it is possible to change a person's reaction to an unfair financial decision" (Fukolova, 2019). Scientists also use other methods of the human brain influencing, such as electric shock, because there are no pain receptors in the brain. Special electrodes are applied and it is possible to suppress or activate certain brain areas by changing the parameters of the electric current.

Naturally, the question arises about the ethical side of research data, as well as the question of the ethical application of obtained knowledges.

Employee of the National Research University "Higher School of Economics" Chernova M.A. and founder and CEO of the research agency inFOLIO Research Group (Moscow) Klepikov O.E. are also concerned about these issues and consider it necessary to determine the range of possible actions related to the ethical component development of the latest neurotechnologies in the field of marketing. This activity should prevent the possibility of causing potential harm to the respondent, as well as form the desire of the professional marketing community to integrate processes with neurosciences and strengthen consumer confidence in this kind of research. The creation of "code of ethics" will prevent the spread of unethical attitudes towards consumers and prevent the possibility of uncontrolled use of information obtained while marketing research (Chernova, Klepikov, 2012).

It seems to us that so-called "ethical code" in the field of neurosciences will have the same impact as the concept of sustainable development declared at the highest level. Obviously, the problem is not in the creation of the relevant documents, but in the dominant ideology, which is based on materialism and atheism, or positivism and social Darwinism. It is necessary to change the methodological platform, only then it will be possible to talk about the moral problems of modern science.

\subsection{Neoholism as an indicator of the sustainable development of society}

At the World Summit on Sustainable Development in Johannesburg, the heads of state and governments agreed that the idea of sustainable development can be realized only if a new society, a new civilization will be built (Nemtsev, 2015). In the 2017 report of the Club of Rome "Come On!: Capitalism, Short-termism, Population and the Destruction of the Planet" authors Ernst Weizsäcker and Anders Wiikman propose some ways to solve these problems (Ursul, 2005).

They propose to refuse the materialism and reductionism in favor of holism and spirituality, they call for an alternative economy, a "New Enlightenment", a planetary civilization, the development of which may be possible on condition of changing the "philosophical roots of the current state of the world". "The current crisis is not cyclical but intensifying. It is not limited by the nature around us, but includes social, political, cultural, moral crisis, crisis of democracy, ideology and the capitalist system" (Ariely, Berns, 2010).

As the world history experience shows, the most important prerequisite for the new civilization formation is a radical transformation of the spiritual (value-semantic) sphere of life. In turn, such transformation is unthinkable without the philosophical project of reconstruction and neoholism, the fundamental value of which is the eidos of harmony, can become such a project.

According to this eidos, the value orientations of sustainable development can be characterized as follows: a) the harmony of a person with himself, which implies the acquisition of the meaning of life and happiness; b) the harmony of a person with society, for 
which the individual must balance his egoistic claims with the interests of the collective, society, state; c) the harmony of society with nature, for which humanity must stop the nature expansion.

The distorted behavioral concepts are approved in society, there is the preference of the rational over the intuitive, science over religion, competition over cooperation, exploitation of natural resources over their conservation and careful use.

Harmonization of all these areas is possible by adequate education and upbringing, that can contribute to the implementation of the following value guideline of the harmony eidos - the harmonization of relations between a person and society by coordination the egoistic aspirations of the individual with the interests of society.

Before the fall of the Roman Empire, it was said: "Luxury is worse than war." The luxury of one person gives rise to the poverty of millions of people, and mass poverty gives rise to the demographic crisis and an ecological catastrophe - everything is interconnected in this world. Therefore, the main task of sustainable development at the present stage is to support the poor and limit the overconsumption of the rich. Any society in the world can not last long if the laws tend to create a rapid accumulation of wealth in a few hands, leaving most of the population in poverty. So, the equalization of the ratio of wealth to poverty at the legislative level, on the one hand, and the creation of a favorable climate for the middle-class development, on the other hand, will contribute to the harmonization if not the whole society but the economic relations in it at least.

\section{Results and discussion}

\subsection{Neuromarketing as the perspective of the civilizational development of society}

In the modern world dominates the ideology of consumption, the products of which are the presence of fashion, wastefulness, profit orientation in decision making, etc. Consumption is the act of receiving goods or services. Overconsumption (or irrational consumption) that dominates in the world and is imposed by the entire marketing system is the phenomenon of receiving goods and services more than need to a greater extent than a person needs. This is a dead end, because of which the entire system is going through a deep crisis.

Some scientists believe that the way out of the crisis is possible through the interaction of science and economics, or rather neurosciences and economics, which leads to overconsumption of goods and services, which means the growth of incomes of large and medium-sized capital. Others see the way out in the new thinking development, a new philosophical paradigm, which must be introduced into the mass consciousness by means of education, thereby raising the level of consciousness and expanding the potential of a person (Deppe, Schwindt, Kugel, Plaßmann, Kenning, 2005; Martinyuk, 2014).

The first option is being actively introduced into public practice, because it is beneficial to large players in the economic and political arena which are very connected. They are completely indifferent to the fact that overconsumption causes numerous contradictions and problems in society (including global ones). The consumer society is initially split as the meaning of consumption lies in individualism. But this contradicts the globalization process as the single human civilization formation.

So, neuromarketing is used, firstly, to influence a person, and secondly, to study the consumer behavior. In other words, it is a scientific approach to promoting and selling a product based on research in neurophysiology, cognitive psychology and marketing. It helps to understand how the mechanism of human perception works in decision-making process. Neuromarketing is a new method of the data obtaining in marketing. The main areas of its application are shown in Figure 1.

Below is the detailed consideration of each of the areas of neuromarketing application.

1. Branding. As the main condition for creating the successful brand is the close interaction of the company with customers at all levels of consumer perception the neuromarketing methods make it possible not only to form the feelings and emotions of customers in the process of interacting with a brand or company's products, but also to influence them in the direction necessary for the company.

2. Product design and innovation. With the help of neuromarketing tools, it is possible to measure customers reactions to product innovations operatively (for example, the updated design) and, that is more important, to regulate the reactions of receiving emotions that are beyond the logical predictions of marketers.

3. The effectiveness of advertising. Neuromarketing allows to see how the influence of advertising on the subconscious of consumers occurs and using the point influence and methods of psychological influence, to increase the advertising effectiveness in many times.

4. Behavioral triggers that influence on the purchasing decisions. Neuromarketing studies which exactly motivators and triggers form consumer's resistant decisions. According to the research, a person makes a purchase decision under the influence of many factors (atmosphere in the store, lighting, temperature, smell), and this often cannot be explained logically. The correct triggers selection gives the necessary effect in the process of decision making on buying the product, even if it is obviously unhealthy or even harmful to a person. 


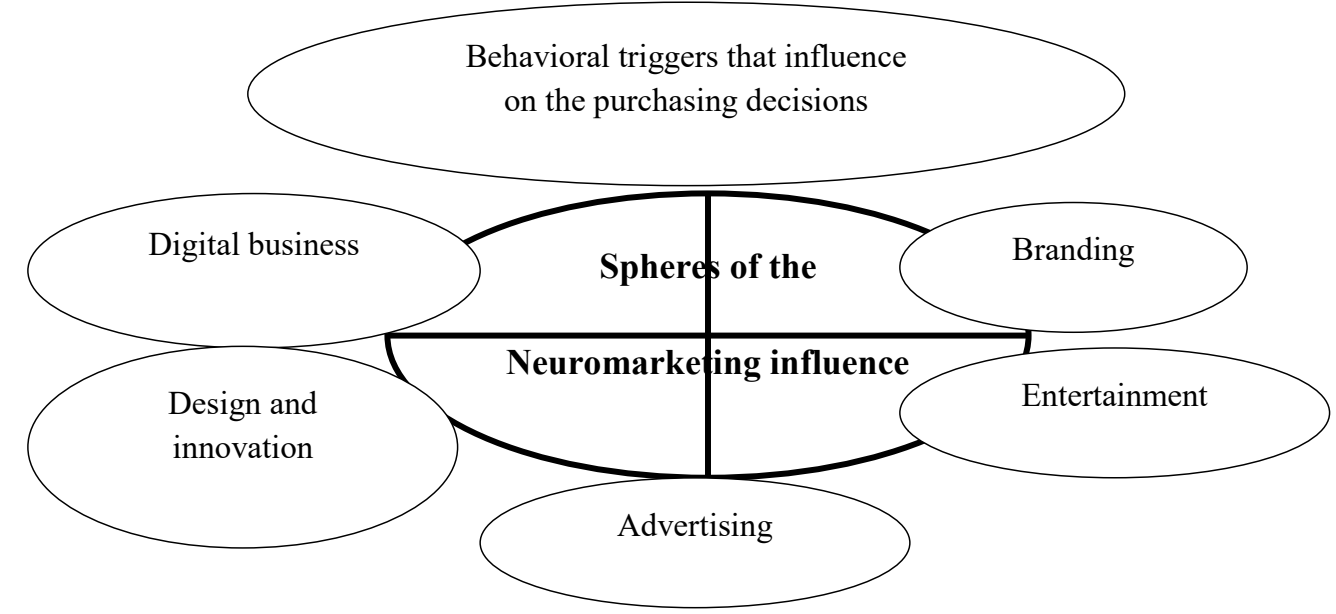

Figure 1. The main areas of the neuromarketing application in the modern conditions

Sources: Plassmann, O'Doherty, Shiv, Rangel, 2008; Lee, Chamberlain, Brandes, 2018

5. Digital business. Neuromarketing helps to form and develop an Internet business competently, allowing to influence the consumer activity of Internet users.

6. Entertainment. The tastes, attitudes and preferences of modern buyers are mostly caused by the experience and emotions that they receive from modern forms of entertainment. In these cases, the rational or moral-ethical factors are not able to influence. Neuromarketing allows to determine the level and degree of impact on the consumer, that means to conduct previously impossible in-depth analysis of behavioral reactions, stereotypes and formats of consumer behavior.

Considering neuromarketing as marketing science, it is advisable to note that the most promising opportunities for receiving positive emotions from the consumer can be achieved through:

1. Objective assessment of the appearance (packaging design, appearance of the final product, advertising visual) using biometric tools.

2. The client's behavior testing on the website, examining the level of his attention and the number of clicks.

3. Psychological tools for assessing the brand or product perception.

4. Formation of the clear phasing of the marketing concept based on the obtained data.

The most famous firms that have used neuromarketing techniques to achieve their goals are Coca-Cola, General Motors, Google Mars, Nestle and many other corporations.

It is important to mention that the neuromarketing cost is increasing every year, for example, in 2015 the United States spent \$25 billion on neuromarketing research (Lee, Chamberlain, Brandes, 2018).

At the present stage, there are three main research methods in neuromarketing: electrical activity of the brain (EEG), oculography (eye movement, eye tracking) and analysis of facial expressions and nonverbal gestures. For example, in the evaluation process of the TV commercials effectiveness, specialists monitor the eyes and determine the speed of pupil movement Öztürk, L. (2018).

The main directions of influence in the critical analysis are below (Ariely, Berns, 2010; Ostapenko, Kolesnyk, 2021).

1. Through the positive emotions formation, it is increased not only the duration of customers stay in stores, but also the number of purchased goods. Neuromarketing most directly influences on the level of emotions and state of comfort, which forms the desire to return regularly.

2. Foreign scientists D. Eraili and G. Bems also mention an important aspect of neuromarketing - the confidentiality violation. According to researchers, companies can "read the minds" of their customers that violates the principle of confidentiality. Transparency of research objectives can solve this problem, so that researchers can know exactly how they are helping the company and which of their data will be used only to achieve the goals. In addition, information about personal preferences should not be declassified.

3. Physiological discrimination. The data obtained in the neuromarketing research may contain information that a particular product is target for people with certain physiological characteristics (possibly defects). This can be used in a discriminatory strategy. In the future it is also possible to introduce an automatic price increase when registering certain parameters of the buyer's body (for example, an increase in the price of a drink if a person feels thirsty).

4. Influence on the highest and lowest levels of moral and ethical motivation. For example, information about the food low in calories affects the highest category of socio-ethical motivation, and advertising 
with erotic content affects the lower levels of moral and ethical motivation. That is an ethically incorrect norm.

5. The dissemination of the data that was collected during the recording of brain activity of subjects in focus groups is extended to the entire population. Design created with insights from neuromarketing research can harm consumers who haven't participated in it.

6. Companies often do not act in the consumers interests. They may be focused on profits maximizing rather than creating a truly useful product. At the same time, neuromarketing researchers can strengthen the possibility of consumer opinion manipulation significantly.

The above indicates the negative aspect of the implementation and active use of neuromarketing tools. However, the progress is developing rapidly, and many phenomena cannot be slowed down or changed. That is why our research is devoted to the necessity of combination of the two conceptual directions of the applied use of neuromarketing as the basis, the superstructure of which must be the humanistic concept of sustainable development that will act as regulator of moral and ethical norms and tools of neuromarketing.

\section{Conclusions}

Humanity has entered a new century that requires the formation of new civilization new society, new ideology. New living conditions and a new environment for existence of the XXI century (under the weight of global problems) come into the conflict with the man of the XX century. The mentality, morality, human activity must be changed in accordance with new time challenges. The vector in the minds of people should be directed from the cult of money and consumption towards respect for nature and man.

Today time requires the revolution of human consciousness. New upbringing, new views of the world, new legislation are needed. This will be facilitated by the new world ideology - sustainable development as consolidating global idea, as the more powerful and urgently needed program of action the implementation of which will be possible on the basis of the neoholism philosophical concept.

Thus, humanity has two paths - the global catastrophe or the sustainable society creation that is the society based on the concept of humanism and neoholism.

Modern neoholism, developed by scientists and philosophers in different countries of our planet, can be the philosophical basis on which it will become possible to form new ideology, new economy, new policy, and, in general, new ecological civilization.

Analyzing the above, it can be argued that neuromarketing in the modern world is one of the leading and promising technologies for the society influencing. It is possible that its potential has not yet been fully formed and studied, but these studies are the highly paid item of expenditure in the large corporations.

\section{References:}

Ariely, D., \& Berns, G. S. (2010). Neuromarketing: the hope and hype of neuroimaging in business. Nature Reviews Neuroscience, 11(4), 284-292.

Bird, K. (2006). Unconscious branding. Computerra, 46, 38-39.

Chernova, M. A., \& Klepikov, O. E. (2012). Neuromarketing: on the ethical issue. National Psychological Journal, 1(7), 139-142.

Deppe, M., Schwindt, W., Kugel, H., Plaßmann, H., \& Kenning, P. (2005). Nonlinear responses within the medial prefrontal cortex reveal when specific implicit information influences economic decision making. Journal of neuroimaging: official journal of the American society of neuroimaging, 15(2), $171-182$. DOI: https://doi.org/10.1111/j.1552-6569.2005.tb00303.x

Fukolova, Y. (2019). Penetrating into the brain of the consumer. Available at: https://hbr-russia.ru/innovatsii/ issledovaniya/a19231

Knutson, B., Rick, S., Wimmer, G. E., Prelec, D., \& Loewenstein, G. (2007). Neural predictors of purchases. Neuron, 53(1), 147-156. DOI: https://doi.org/10.1016/j.neuron.2006.11.010

Lee, N., Chamberlain, L., \& Brandes, L. (2018). Welcome to the jungle! The neuromarketing literature through the eyes of a newcomer. European journal of marketing, 52(1/2), 4-38. DOI: https://doi.org/10.1108/EJM-022017-0122

Lim, W. M. (2018). Demystifying neuromarketing. Journal of business research, 91, $205-220$. DOI: https://doi.org/10.1016/j.jbusres.2018.05.036

Lindstrom, M. (2012). Buyology: a fascinating journey into the brain of the modern consumer / translated from English. Moscow: Alpina Business Books.

Martinyuk, O. A. (2014). Creation of intelligent business processes of agroholding. Actual Problems of Economy, 6(156), 234-240.

Murphy, E. R., Illes, J., \& Reiner, P. B. (2008). Neuroethics of neuromarketing. Journal of consumer behaviour, 7(4-5), 293-302. DOI: https://doi.org/10.1002/cb.252 
Vol. 2 No. 3, 2021

Nemtsev, I. A. (2015). Sustainable Development Strategy as the Integration Core of the Eurasian Union. Politics and Society, 1, 91-106.

Plassmann, H., O’Doherty, J., Shiv, B., \& Rangel, A. (2008). Marketing actions can modulate neural representations of experienced pleasantness. Proceedings of the national academy of sciences, 105(3), 1050-1054. DOI: https://doi.org/10.1073/pnas.0706929105Yağci

Kuhzady, S., Balik, Z. S., \& Öztürk, L. (2018). In search of consumer's black box: a bibliometric analysis of neuromarketing research. Journal of consumer and consumption research, 10(1), 101-134.

Ostapenko, T., \& Kolesnyk, M. (2021). Nanoeconomics and innovative marketing as factors of sustainable development in global environment. Baltic Journal of Economic Studies, 7(3), $159-167$. DOI: https://doi.org/10.30525/2256-0742/2021-7-3-159-167

Plotnikov's Dictionary. Available at: http://slovar-lopatnikov.ru/slovar/u/ustojchivoe-razvitie/

Ursul, A. D. (2005). Sustainable development: a conceptual model // National interests, no. 1. Available at: http://ni-journal.ru/archive/2005/n1_05/5324690e/d93f12df/ 